\title{
Stranding events of southern right whales, Eubalaena australis, in southern Brazil
}

\author{
Antonio B. Greig, Eduardo R. Secchi, Alexandre N. Zerbini and Luciano Dalla Rosa \\ Laboratory of Marine Mammals, Museu Oceanográfico 'Prof. Eliézer de Carvalho Rios', Rua Cel. Heitor Perdigão $n^{\circ} 10$, \\ C.P. 379, Rio Grande, RS, Brazil 96500-970 \\ Contacte-mail: tony@hidrosfera.com
}

\begin{abstract}
Although international protection has been granted since 1935, southern right whales have only recently shown signs of recovery, possibly due to anthropogenic factors. Off Brazil, illegal hunting of right whales occurred until 1973. This paper reports on surveys conducted along the southern Brazilian coast and the information recovered on right whale strandings for this area from 1977-1995. In the first 10 years of this period only four cases were registered. However, in contrast, 20 cases were counted during the last nine years. These results are discussed in relation to marine traffic and the fisheries in the area that produce risks of collision and entanglement. Further, the possibility of storm surges being a preponderant factor in the mortalities in this area is presented. These yearly rates are compared with neighbouring areas that are also inhabited by the right whales. Both possibilities fit the hypothesis that the right whales using the Brazilian coast for breeding may finally be showing signs of recovery.
\end{abstract}

KEYWORDS: SOUTHERN RIGHT WHALE; ATLANTIC OCEAN; STRANDINGS; SURVEY-SHORE-BASED; SOUTHERN HEMISPHERE; SOUTH AMERICA

\section{INTRODUCTION}

When North Atlantic right whales (Eubalaena glacialis) were showing first signs of depletion, whalers turned their attention to the southern right whales (Eubalaena australis). They were intensively hunted throughout the Southern Hemisphere to near commercial extinction (e.g. see the summary in IWC, 2001).

In 1935, right whales received their first international protection and this was continued after the signing of the International Convention for the Regulation of Whaling in 1946 (Donovan, 1992). Recently, there has been evidence of recovery in several Southern Hemisphere populations; however, the same is not true for the North Atlantic or North Pacific right whales (IWC, 2001).

Intensive studies of southern right whales off the eastern coast of South America began in 1971, at the Península Valdéz nursery area off the Argentinian coast. Photo-identification methods have proved particularly successful for examining behaviour as well as estimating population parameters (e.g. Payne et al., 1990). Similar studies have been carried out off South Africa (e.g. Best, 1981), Tristan da Cunha (Best, 1988) and, to a lesser extent off the southern Brazilian coast (Simões-Lopes et al., 1992; Best et al., 1993). These studies have provided an insight into the major migration routes of the species in the South Atlantic (Best et al., 1993). The population that breeds off Argentina also uses Tristan da Cunha and the Brazilian coast as breeding grounds, as well as an area off South Georgia for feeding (IWC, 2001).

In Brazil, whaling began in the $17^{\text {th }}$ century in the state of Bahia and had expanded along the coast to Santa Catarina by the $19^{\text {th }}$ century (Ellis, 1969). Even after international protection, it appears that some right whales were hunted illegally in Brazil until 1973 (Palazzo and Carter, 1983; Tormosov et al., 1998).

Strandings of South Atlantic right whales in their major breeding grounds appear to be rare and are usually reported when they are the result of interactions with vessels or fishing gear (e.g. Best, 1984). Since 1977, southern right whale strandings off the Brazilian coast have been reported in the literature or recorded in log books, irrespective of their cause. Such data are relatively easy to obtain and do not involve great costs or major research programmes.

This paper reports on right whale stranding events along the southern coast of Brazil between 1977 and 1995.

\section{MATERIALS AND METHODS}

This study was carried out along the state of Rio Grande do Sul, Brazil, which shares borders with Uruguay to the south and with the Brazilian state of Santa Catarina to the north

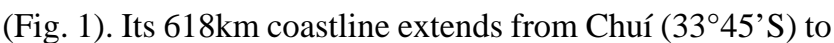
Torres $\left(29^{\circ} 19^{\prime} \mathrm{S}\right)$. Beach surveys by car along the $400 \mathrm{~km}$ stretch between Chuí and Mostardas $\left(31^{\circ} 10^{\prime} \mathrm{S}\right)$ to record stranded animals were carried out from 1989-1995. Further information on strandings was obtained from media files, researchers from other laboratories that surveyed the complete Rio Grande do Sul State coastline during their studies and from marine mammal researchers who had previously covered the same area. Records of sightings of mother-calf pairs along the study area were also obtained in the same way.

Survey effort varied over the total period of this study. Information from 1977-1986 was collected during surveys undertaken by a number of researchers. These surveys covered $100 \mathrm{~km}$ every two weeks or alternately, $400 \mathrm{~km}$ to the north in one month and $220 \mathrm{~km}$ to the south in the other. Effort was not constant throughout the ten year period, being less intense at the beginning and at the end. From 1987-1990, surveys were carried out opportunistically. In 1991, a regular programme was established and surveys were carried out every two weeks, covering alternately $220 \mathrm{~km}$ to the south and $200 \mathrm{~km}$ to the north.

Any animals found dead were photographed and sexed and measured according to Leatherwood et al. (1982). Some individuals found were too decomposed to determine sex and there were other cases where the recorded information provided little detail. Some parts of the skeletons were recovered and deposited in the collection at the Museu Oceanográfico 'Prof. Eliézer de C. Rios' in Rio Grande. 


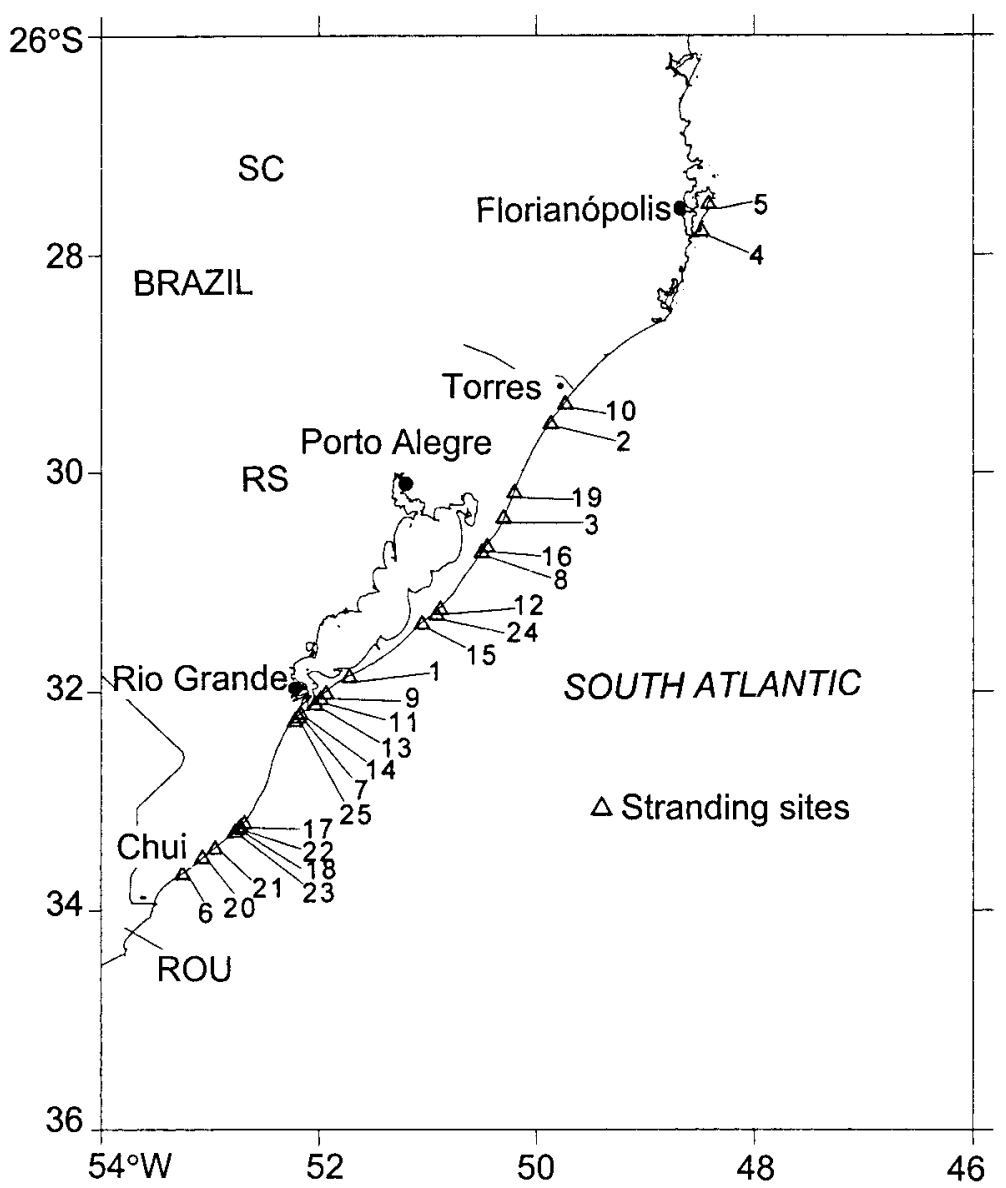

Fig. 1. Southern right whale stranding sites on the southern Brazilian coast between 1977 and 1995. ROU = Oriental Republic of Uruguay; RS=Rio Grande do Sul State in Brazil; SC = Santa Catarina State in Brazil. The numbers are related to those of Table 1 .

\section{RESULTS}

A total of 12 mother-calf sightings from shore were recorded between 1983 and 1994 (1 in 1983, 1985, 1988 and 1989, 3 in 1991, 4 in 1992 and 2 in 1994) showing a slight increase over time. Photographs of the pairs showed that they were not resightings. Twenty-three strandings/beachings were recorded between 1977 and 1995 along the Rio Grande do Sul State coast (Table 1). Four occurred from 1977-1986 and the other 19 from 1987-1995. The highest numbers occurred during the month of October but strandings also occurred in late winter (August and September). Nine individuals were calves, while 14 were sub-adults or adults.

In 1989, a young right whale was found washed ashore with propeller cuts on its head; it had been sighted several times with two other adult whales during the two previous weeks (Secchi, 1994). In 1991, two halves of a right whale were found about half a mile apart from each other. In the same year, an adult male that had been reported by the Navy as floating dead two days before was found on the beach. In 1992, a fisherman reported having collided with a right whale during trawling but no dead whale was later found. In October 1993, a right whale was found beached $16 \mathrm{~km}$ south of Rio Grande $\left(32^{\circ} 08^{\prime} \mathrm{S}\right)$ with four propeller cuts on its caudal stock.

On 14 October 1987, a 5m male was found stranded on Cassino beach ( $32^{\circ} 10^{\prime} \mathrm{S}$; F. Rosas, pers. comm.). On 5 August 1992, a $6 \mathrm{~m}$ female still with vestiges of the umbilical cord was found stranded at Cidreira $\left(30^{\circ} 10^{\prime} \mathrm{S}\right)$ (L. Susin, pers. comm.). On 9 October 1993, a 5.5m female was found stranded close to the Mostardas lighthouse ( $\left.31^{\circ} 13^{\prime} \mathrm{S}\right)$;
Table 1

Southern right whale stranding events on the southern coast of Brazil, between 1977 and 1995. Cases 4 and 5 were in the state of Santa Catarina.

\begin{tabular}{|c|c|c|c|c|}
\hline Case & Date & Length (m) & Sex & Source \\
\hline 1 & 26 Aug. 1977 & 14.00 & $\mathrm{~F}$ & Castello and Pinedo, 1979 \\
\hline 2 & 1 Aug. 1979 & Calf & Ind. & Palazzo and Carter, 1983 \\
\hline 3 & 1 Sep. 1982 & Calf & Ind. & Palazzo and Carter, 1983 \\
\hline 4 & 25 Aug. 1983 & Calf & Ind. & Lodi et al., 1996 \\
\hline 5 & 28 Sep. 1983 & Calf & Ind. & Lodi et al., 1996 \\
\hline 6 & 1 Nov. 1984 & 12.00 & Ind. & Lodi et al., 1996 \\
\hline 7 & 31 Aug. 1987 & 17.50 & $\mathrm{M}$ & F.W. Rosas, pers. comm. \\
\hline 8 & 17 Sep. 1987 & 13.00 & Ind. & CEBECLIM \\
\hline 9 & 14 Oct. 1987 & 5.00 & $\mathrm{M}$ & F.W. Rosas, pers. comm. \\
\hline 10 & 8 Sep. 1988 & 6.00 & Ind. & CEBECLIM \\
\hline 11 & 25 Aug. 1989 & 7.50 & $\mathrm{M}$ & Secchi, 1994 \\
\hline 12 & 26 Sep. 1990 & 15.00 & $\mathrm{~F}$ & NEMA \\
\hline 13 & 30 Sep. 1990 & 14.50 & $\mathrm{~F}$ & - \\
\hline 14 & 8 Oct. 1991 & 13.50 & M & - \\
\hline 15 & 12 Oct. 1991 & 14.00 & $\mathrm{M}$ & L. Calliari, pers. comm. \\
\hline 16 & 12 Oct. 1991 & Adult & Ind. & L. Calliari, pers. comm. \\
\hline 17 & 14 Feb. 1992 & $\mathrm{xx}$ & Ind. & - \\
\hline 18 & 14 Feb. 1992 & Calf & Ind. & - \\
\hline 19 & 5 Aug. 1992 & 6.00 & $\mathrm{~F}$ & L. Susin, pers. comm. \\
\hline 20 & 2 Oct. 1992 & 14.30 & Ind. & - \\
\hline 21 & 16 Aug. 1993 & Ind. & Ind. & - \\
\hline 22 & 9 Oct. 1993 & 10.50 & M & - \\
\hline 23 & 9 Oct. 1993 & 4.58 & Ind. & - \\
\hline 24 & 9 Oct. 1993 & 5.54 & $\mathrm{~F}$ & - \\
\hline 25 & 25 Oct. 1993 & 12.50 & M & - \\
\hline
\end{tabular}

another whale measuring $4.6 \mathrm{~m}$ was also found stranded close to the Albardão lighthouse $\left(33^{\circ} 12^{\prime} \mathrm{S}\right)$. These four individuals were probably neonates. 


\section{DISCUSSION}

The number of strandings found during the second period of this study (19 in nine years) is high when compared to the four cases that occurred during the first period (10 years) of our study. It is important to note that in the neighbouring state of Santa Catarina, which is the main breeding ground for the species in Brazil (Simões-Lopes et al., 1992) and where the search effort was also high, only two strandings were registered during the total period (19 years) (J.T. Palazzo Jr., pers. comm.).

This increase in sightings and strandings in the study area might imply that the species is returning to its historical breeding grounds, as has also been suggested by Castello and Pinedo (1979), Lodi and Bergallo (1984), Câmara and Palazzo Jr. (1986) and Simões-Lopes et al. (1992). If there has been a real increase in the number of individuals using the Brazilian coast, it might be reasonable to expect that strandings would also be more frequent. An increase in the number of individuals in this general area would also increase the likelihood of collisions with marine traffic. This would be similar to the problem reported by Wiley et al. (1995), who described a notable increase in the number of humpback whale strandings between two similar periods on the southeastern coast of the USA. They noted that this might be attributed at least in part to an increase in the number of juveniles using that coastal habitat with the associated increase in the probability of collisions.

Anthropogenic activities are one cause of right whale mortality off the Rio Grande do Sul coast. Three of the 23 stranding cases showed evidence of anthropogenic interaction, whilst the other cases were not sufficiently investigated to determine the cause of death. Marine traffic in the area is extensive due to the presence of the Port of Rio Grande, which is the only fishing facility on the state coast and therefore attracts most of the fishing fleet of southern Brazil. Approximately 535 fishing boats operate in the area all year round (IBAMA, unpublished data).

Sciaenids represent an important fishing resource for the local fleet (approximately $81 \%$ in weight of the region's bony fish; Haimovici et al., 1996) as well as for boats from neighbouring Santa Catarina (Haimovici et al., 1989; Reis, 1992). The operating range of most vessels in these fleets is up to the $80 \mathrm{~m}$ isobath, an area that corresponds with the coastal migration route of right whales to and from their wintering grounds. This overlap between fishing and migration areas causes potential risk of collisions and entanglements. In addition, the port of Rio Grande receives an average of $1,435(n=$ eight years of data) cargo ships per year, although most of this traffic occurs during the first months of winter $\left(5^{\text {th }}\right.$ Naval District, unpublished data) and is therefore before the months in which most of the strandings were observed. In this context, however, it is interesting to note that while Santa Catarina has more than one port (including the Port of Itajaí, a large fisheries port) and its coastline is the major breeding ground for right whales in Brazil, few strandings have been reported here. The survey effort in the region was as extensive as that further south in Rio Grande do Sul.

Despite the extensive fishing effort off the coast of Rio Grande do Sul, to date no cases of entanglement in fishing gear have been recorded. This may reflect the fact that most of the fisheries target bottom-dwelling species using either bottom-set or trawl gear (right whales spend most of their time near the surface during migration making it unlikely that they would become entangled in bottom gear). Along the coasts of Santa Catarina and Rio de Janeiro, six and three entanglements have been reported respectively (Lodi et al., 1996). Here, by contrast, although coastal fisheries are not as common as off Rio Grande do Sul, they use surface-set gear in the shallow waters where right whales breed.

That right whales are vulnerable to ship strikes and entanglements has been shown in other areas (IWC, 2001). Kraus (1990) and Knowlton and Kraus (2001) reported that collisions with vessels and entanglements in fishing nets were significant causes of mortality in the northwest Atlantic. Best et al. (2001) summarises ship strikes and entanglements of right whales off the South African coast. The lack of stranding records of southern right whales connected with shipping accidents in Australian waters is thought to be due to the fact that, at present, the species is rarely found in the major ports and shipping channels of Southern Australia and New Zealand; prior to the 1850s these areas were part of their range and were used as nursery/calving grounds (F. Michaellis, pers. comm.).

The continental shelf off Rio Grande do Sul is extensive, has a gentle slope and the coastline is open and sandy, compared to that of Santa Catarina which has several bays and opportunities for shelter (Fig. 1). These features make stranding events more likely here when compared with Santa Catarina. Storms usually hit the coast from the south or southeast, pushing water up against the shore and producing a storm surge; this can result in an elevation of sometimes more then two meters above the normal sea level (Calliari et al., 1997). Right whales using this coast as a migration route, calving or nursing ground, may try to seek shelter closer to the shore during strong storms and thus end up stranded. This situation would be unlikely in Santa Catarina due to the greater number of shelter opportunities and this could account for its low number of stranding events (only two during the study period). It is interesting to note that Ellis (1969) deduced from whaling accounts that southern winds were favourable for whaling off the Brazilian coast because the whales came closer to the shore.

Little is known about the migration route of southern right whales off the Brazilian coast. The period in which most strandings occurred is consistent with the May-December period reported by Lodi and Bergallo (1984). Sightings of mother-calf pairs close to the shore (e.g. Secchi, 1994) as well as the stranding of neonates on the Rio Grande do Sul coast indicate that the groups seen are either returning from calving areas further north or that the Rio Grande do Sul coast is used as a calving and nursery area (although to a lesser extent than the Santa Catarina coast). However, Simões-Lopes et al. (1992) had affirmed that while the Santa Catarina coast is used for mating, calving and nursing, the Rio Grande do Sul coast is used mostly as a migration path. Thomas and Taber (1984) suggest that nursing in southern right whales at Península Valdés can last up to 14 months after birth. The sightings and strandings of newborns and mother/calf pairs reported here provide evidence that the Rio Grande do Sul coast may represent a calving/nursing area for the species.

In conclusion, there are several factors that may explain the relatively high number of stranding events in this area compared with the major breeding ground in Santa Catarina. These include: (1) increase use by whales, possibly as a breeding ground; (2) exposed open coast that favours stranding events; and (3) greater probability of collisions with fishing and cargo vessels. It is strongly recommended that directed studies to establish the importance of this coast as a breeding ground and migration route be carried out. 


\section{ACKNOWLEDGEMENTS}

The authors would like to thank the anonymous reviewers and G.P. Donovan for their valuable suggestions on the manuscript. We are also indebted to Lauro Barcellos (Director of the Museu Oceanográfico 'Prof. Eliézer C. Rios') for the logistical support necessary for the development of this study. Our colleagues Luciana Möller and Manuela Bassoi helped collect the data presented in this manuscript, and Fernando Rosas, José Truda Palazzo, Loredana Susin, Lauro Calliari and CEBECLIM contributed further information on strandings. Mônica Muelbert, Lauro Calliari and Valdir Pinto provided important suggestions to the manuscript. Financial support was granted by Fundação 'O Boticário de Proteção à Natureza'. During part of this study one of us (ERS) received a scholarship from the Brazilian Council for Research and Development (CNPq).

\section{REFERENCES}

Best, P.B. 1981. The status of right whales (Eubalaena glacialis) off South Africa, 1969-1979. Investl Rep. Div. Sea Fish. S. Afr. 123:1-44.

Best, P.B. 1984. The southern African right whale census, 1984. Afr. Wildl. 38(6):242.

Best, P.B. 1988. Right whales, Eubalaena australis, at Tristan da Cunha. A clue to the 'non-recovery' of depleted stocks? Biol. Conserv. 46:23-51.

Best, P.B., Payne, R., Rowntree, V., Palazzo, J.T. and Both, M.D. 1993. Long-range movements of South Atlantic right whales, Eubalaena australis. Mar. Mammal Sci. 9(3):227-34.

Best, P.B., Peddemors, V.M., Cockcroft, V.G. and Rice, N. 2001. Mortalities of right whales and related anthropogenic factors in South African waters, 1963-1998. J. Cetacean Res. Manage. (special issue) $2: 171-176$.

Calliari, L.J., Tozzi, H.M. and Klein, A.H.F. 1997. Beach response and coastline association with storm surges in southern Brazil - Rio Grande to Chuí, R.S. Coastal Environment Management and Conservation, Tome 2, Actes du Colloque, Bordeaux, France.

Câmara, I.G. and Pallazzo Jr, J.T. 1986. Novas informações sobre a presença de Eubalaena australis no sul do Brasil. $1^{a}$ Reunión de Trabajo de Expertos en Mamíferos Acuáticos de América del Sur. Buenos Aires, 1984. Actas, p.35-41. [In Portugese].

Castello, H.P. and Pinedo, M.C. 1979. Southern right whales (Eubalaena australis) along the southern Brazilian coast. $J$. Mammal. 60(2):429-30.

Donovan, G.P. 1992. The International Whaling Commission: Given its past, does it have a future? pp. 23-44. In: J.J. Symoens (ed.) Symposium «Whales: Biology - Threats - Conservation». Royal Academy of Overseas Sciences, Brussels, Belgium. 261pp.

Ellis, M. 1969. A Baleia no Brasil Colonial. Ediçoes Melhoramentos, Editora da Universidade de São Paulo, São Paulo, Brasil. 235pp. [In Portuguese].

Haimovici, M., Pereira, S.D. and Vieira, P.C. 1989. La pesca demersal en el sur de Brasil en el periodo 1975-1985. Frente Marítimo 5A:151-63. [In Spanish].
Haimovici, M., Martins, A.S. and Vieira, P.C. 1996. Distribuição e abundância de peixes teleósteos sobre a plataforma continental do Sul do Brasil. Revista Brasileira de Biologia 56(1):27-50. [In Portuguese].

International Whaling Commission. 2001. Report of the Workshop on the Comprehensive Assessment of Right Whales: A worldwide comparison. J. Cetacean Res. Manage. (special issue) 2:1-60.

Knowlton, A. and Kraus, S. 2001. Mortality and serious injury of northern right whales (Eubalaena glacialis) in the western North Atlantic Ocean. J. Cetacean Res. Manage. (special issue) 2:193-207.

Kraus, S.D. 1990. Rates and potential causes of mortality in North Atlantic right whales (Eubalaena glacialis). Mar. Mammal Sci. 6(4):278-91.

Leatherwood, S., Reeves, R.R., Perrin, W.F. and Evans, W.E. 1982. Whales, dolphins and porpoises of the eastern North Pacific and adjacent waters: a guide to their identification. NOAA Technical Report, NMFS Circular 444. 245pp.

Lodi, L.F. and Bergallo, H.G. 1984. Presença da baleia-franca (Eubalaena australis) no litoral brasileiro. Boletim da Fundação Brasileira para a Conservação da Natureza 19:157-63. [In Portuguese].

Lodi, L., Siciliano, S. and Bellini, C. 1996. Ocorrências e conservaçao de baleias-francas-do-sul, Eubalaena australis, no litoral do Brasil. Pap. Avulsos dep. Zool. (Sao Paulo) 39(17):307-328. [In Portuguese].

Palazzo, J.T., Jr. and Carter, L.A. 1983. A caça de baleias no Brasil. Porto Alegre: Assoc. Gaúcha de Prot. Amb. Natural. 25pp. [In Portuguese].

Payne, R., Rowntree, V., Perkins, J.S., Cooke, J.G. and Lankester, K. 1990. Population size, trends and reproductive parameters of right whales (Eubalaena australis) off Peninsula Valdes, Argentina. Rep. int. Whal. Commn (special issue) 12:271-8.

Reis, E.G. 1992. An assessment of the exploitation of the white croaker, Micropogonias furnieri (Pisces, Sciaenidae) by the artisanal and industrial fisheries in coastal waters of southern Brazil. PhD Thesis, University of East Anglia. 219pp.

Secchi, E.R. 1994. Informaçoes ineditas sobre a presença da Eubalalena australis na costa sul do Rio Grande do Sul - Brasil. Actas da IV Reuniao de Trabalhos de Especialistas em Mamiferos Aquáticos da America do Sul, Valdivia. pp.234-243. [In Portuguese].

Simões-Lopes, P., Palazzo Jr, J.T., Both, M.C. and Ximénez, A. 1992. Identificação, movimentos e aspectos biológicos da baleiafranca-austral (Eubalaena australis) na costa sul do Brasil. III Reunión de Trabajo de Expertos en Mamíferos Acuáticos de América del Sur. Montevideo, 1988. Anales, p.62-65. [In Portuguese].

Thomas, P.O. and Taber, S.M. 1984. Mother-infant interaction and behavioral development in southern right whales, Eubalaena australis. Behaviour 88(1-2):42-60.

Tormosov, D.D., Mikhalev, Y.A., Best, P.B., Zemsky, V.A., Sekiguchi, K. and Brownell Jr, R.L. 1998. Soviet catches of southern right whales, Eubalaena australis, 1951-1971; biological data and conservation implications. Biol. Conserv. 86(2):185-97.

Wiley, D.N., Asmutis, R.A., Pitchford, T.D. and Gannon, D.P. 1995. Stranding and mortality of humpback whales, Megaptera novaeangliae, in the mid-Atlantic and southeast United States, 1985-1992. Fish. Bull. 93(1):196-205. 